\title{
Evolutive History of Leishmania Genus and Differential Diagnosis of Clinical Important Species Based on A Unique Kinetoplastida Chitinase
}

\section{Aline Diniz Cabral}

Universidade Federal do ABC

Felipe Trovalim Jordão

Universidade Federal do ABC

Gabriel Lopes Pereira

Universidade Federal do ABC

Leticia Abrantes de Andrade

Universidade Federal do ABC

\section{Edmar Silva Santos}

Universidade Federal do ABC

\section{Rodrigo Buzinaro Suzuki}

Universidade Federal do ABC

Max Mario Fuhlendorf

Universidade Federal do ABC

\section{Lucas Gentil Azevedo}

Fiocruz Bahia: Centro de Pesquisas Goncalo Moniz

\section{Pablo Ivan Pereira Ramos}

Fiocruz Bahia: Centro de Pesquisas Goncalo Moniz

Artur Trancoso Lopo de Queiroz

Fiocruz Bahia: Centro de Pesquisas Goncalo Moniz

Márcia Aparecida Sperança ( $\square$ marcia.speranca@ufabc.edu.br )

Universidade Federal do ABC https://orcid.org/0000-0002-1178-3747

\section{Research Article}

Keywords: Marine-derived chitinase, Leishmania, molecular diagnosis, Leishmania evolution theory.

Posted Date: July 9th, 2021

DOl: https://doi.org/10.21203/rs.3.rs-676457/v1 
License: (c) (i) This work is licensed under a Creative Commons Attribution 4.0 International License. Read Full License 


\section{Abstract}

Leishmaniasis, a neglected infectious disease affecting humans, domestic and wild animals, caused by 20 from 53 Leishmania genus species, is transmitted by sandflies. Leishmania genus, belonging to Trypanosomatide Family and Kinetoplastida Order, are grouped in five subgroups according to biogeographic and evolutive history of parasites and hosts, which has led to incongruences and paraphyly. The GH18 Leishmania chitinase, encoded by a specie-specific single copy gene, conserved in basal groups of trypanosomatids, and absent in the genus Trypanosoma, was evaluated as a phylogenetic marker and a diagnostic target. Primers were designed to detect Leishmania in its host biological samples and to obtain the chitinase sequence of species not available in public databanks. The GH18 chitinase gene and its genomic context was evaluated phylogenetically. A protocol to discriminate among Leishmania subgenera by PCR and restriction fragment length polymorphism (RFLP) was developed using in silico tools. A PCR method to detect a partial 953 bp GH18 quitinase encoding gene presented high sensibility and specificity on isolated parasites DNA and using as negative controls, Trypanosoma cruzi, and DNA from Leishmania hosts. Preservation of the chitinase locus in the aquatic free-living protozoan Bodo saltans, disclose a primitive common origin. GH18 trypanosomatide chitinase amino acid sequence comparative analysis revealed high similarity to chitinase from marine prokaryotes and protozoan. Phylogenetic reconstruction based on chitinase corroborates the Supercontinent Origins theory for Leishmania. The chitinase encoding gene was effectively detected in biological samples and for differential molecular diagnosis among Leishmania clinical important species worldwide.

\section{Introduction}

Protozoan parasites of the Leishmania genus are the causative agents of multiple leishmaniases manifestations that affect humans, domestic dogs, and wild animal hosts, all of them transmitted by insect vectors of the Psycodidae Family (sand flies) of which Phlebotomus (Old World) and Lutzomyia genus (New World - the Americas) are amongst the most important (Akhoundi et al., 2016b). The 53 Leishmania species are divided into five subgenera: Leishmania, Viannia, Sauroleishmania, Mundinia and Paraleishmania. Of these, 20 species are implicated to cause human disease, and most of them are zoonotic (Akhoundi et al., 2016b).

Leishmaniases can range from mild tegumentar ulcerations (tegumentary leishmaniasis, $T L$ ) to fatal visceral infection (visceral leishmaniasis, VL) depending on parasite species and host immunity conditions. It is estimated that up to 0.4 and 1.2 million cases of VL and TL, respectively, occur in 98 endemic countries each year (Alvar et al., 2012). Brazil predominantly accounts for the highest incidence in the Americas, where TL is widely spread and VL is expanding (Georgiadou, Makaritsis, and Dalekos, 2015). VL poses important concerns for human health, causing over 50,000 deaths annually, and in India and Mediterranean countries is caused by L. (Leishmania) donovani and L. (Leishmania) infantum, respectively (2017). In the Americas this disease is also caused by L. infantum, which probably entered the region by Mediterranean colonizers carrying infected dogs (Marcili et al., 2014). TL causes morbidity and disfiguring scars in various regions worldwide, but Afghanistan, Algeria, Colombia, Brazil, Iran, Syria, 
Ethiopia, Sudan, Costa Rica and Peru together account for more than $75 \%$ of new cases (2017). In South America, TL mainly caused by the most prevalent Leishmania species, viz., L. (Viannia) braziliensis, L. (Leishmania) amazonensis and L. (Leishmania) mexicana, is endemic. In spite of much efforts, a precise diagnostic test and effective treatment for leishmaniasis are still unavailable (Scheufele, Giesey, and Delost, 2020). Thus, a detailed understanding of all aspects of specific biology and host-parasite relationships is important prior to facilitating the formulation of innovative and effective drugs and diagnostic tests for developing adequate prevention and control strategies.

The evolutionary origins of Leishmania parasites and their genetic relationships can be investigated using phylogenetic reconstructions associated to data on biogeographic dispersion and evolution of their vertebrates and sand flies hosts. Three main theories have been proposed for Leishmania origin: 1) a Palearctic, Neotropical; 2) a Neotropical/ African; 3) multiple, independent origins (Akhoundi et al., 2016b).The most supported theory for Leishmania origin corresponds to the Supercontinent hypothesis, a variation to the Multiple Origins hypothesis, which denotes the independent evolution of the Viannia and Leishmania subgenera during the separation of South America from Africa. The Supercontinent hypothesis places the origin of Leishmania on Gondwana, emerging from monoxenous parasites (Harkins et al., 2016) and is in agreement with biogeographic data, animals' host migration propositions and was supported by a comprehensive phylogenetic analysis using a large multi-gene dataset (over 200,000 informative sites) (Harkins et al., 2016). An important caveat in phylogenetic reconstruction of basal trypanosomatids, including Leishmania species, relies on our limited knowledge of their specie and genera specific sequence diversity, partly due to the difficulties of in vitro culture isolation. Thus, in this paper the Trypanosomatidae GH18 chitinase is explored as a molecular marker to identify Leishmania species directly from biological specimens, to differentially diagnose the clinically worldwide important species, and to conduct evolutionary studies of the Leishmania phylogenetic relationships.

\section{Material And Methods}

\section{Cultivation and DNA extraction of Leishmania reference species.}

The Leishmania reference strains used in this study are identified in Table 1 and were obtained from the National Leishmania Typing Reference Laboratory, Leishmaniasis Research Laboratory, Oswaldo Cruz Institute, Oswaldo Cruz Foundation, Ministry of Health. Cultivation of the Leishmania reference species were performed in M199 or LIT culture media. Exponentially growing cultures were centrifuged and frozen in $2 \mathrm{~mL}$ cryogenic tubes in liquid nitrogen after addition of culture medium with $20 \%$ DMSO and $10 \%$ fetal bovine serum. An aliquot of $2 \mathrm{~mL}$ of the culture of each Leishmania species was subjected to DNA extraction using the DNeasy ${ }^{\circledR}$ Blood \& Tissue Kit (QIAGEN ${ }^{\circledR}$, Valencia, CA, USA) according to manufacturer instructions. Quality of DNA was determined by $1 \%$ agarose gel electrophoresis stained with Unisafe (Uniscience) and quantification was performed using the Low Mass Ladder (ThermoFisher Scientific). 
To amplify specifically the chitinase-encoding gene from Leishmania spp., oligonucleotides were designed after multiple alignment of chitinase gene sequences available in public databanks (Table 1), using Clustal $X$ v.2.1. Sequence specificity and secondary structure medium temperature (Tm) were evaluated by primer-Blast (Ye et al., 2012) and Mfold (Zuker, 2003), respectively. Temperature and PCR cycling conditions to obtain high specificity and sensitivity of the oligonucleotides were tested with Platinum Taq DNA Polymerase (Invitrogen), DNA from different Leishmania species and DNA from human, phlebotomines, dogs, cats, and Trypanosoma cruzi as negative controls. Several oligonucleotides sets were tested and the Lquit224F (5' GTTCMACTACGAGGCCTTCTTCAA3') and Lquit1182R (5' CAGATCATTATCCCAGACAAGTT 3'), which amplify a 953 bp fragment corresponding to the single copy chitinase-encoding gene was selected due to its sensitivity and specificity to detect Leishmania species. Using Lquit224F and Lquit 1182R the partial chitinase gene sequence from the species $L$. guyanensis, $L$. shawi, L. lainsoni, L. naiffi and L. amazonensis not available in public databank, was obtained through PCR using Platinum Taq DNA polymerase High Fidelity (Invitrogen). The PCR reactions were conducted in a 9700 Perkin Elmer Termocycler and conditions used were $94^{\circ} \mathrm{C}$ for 3 min followed by 40 cycles of $94^{\circ} \mathrm{C}$ for $1 \mathrm{~min} ; 64^{\circ} \mathrm{C}$ for $30 \mathrm{~s} ; 72^{\circ} \mathrm{C}$ for $45 \mathrm{~s}$; and $72^{\circ} \mathrm{C} 7 \mathrm{~min}$. Chitinase amplicons were cloned into $P G E M-T$ (Promega), transformed in Escherichia coli Mach T1; and the clones were selected by PCR miniscreen with the oligonucleotides M13F and M13R. Two clones carrying the chitinase amplicon from each Leishmania species were sequenced by Sanger method using BigDye 3.1 Terminator Cycle Sequencing Kit (Perkin Elmer) in an automatic sequencer ABI 310 (Applied Biosystems).

All available chitinase $953 \mathrm{bp}$ fragment sequences deposited in public databank and the sequences generated in this study (Table 1) were subjected to alignment and selection for restriction enzymes sites, using the software GeneQuest from Lasergene (Burland, 2000), to discriminate among Leishmania subgenera employing PCR followed by restriction fragment length polymorphism (PCRRFLP).

\section{Phylogenetic analysis}

To perform the phylogenetic reconstruction of trypanosomatids harboring the chitinase gene, a $953 \mathrm{bp}$ of the encoding gene from Leishmania species and others reference trypanosomatids were obtained from GenBank and EMBL (Table 1). Gene multiple alignment was carried out using Muscle version 3.8.3 (Edgar, 2004) and manually curated (Okonechnikov et al., 2012). Phylogenetic reconstruction was performed using the maximum likelihood method in PhyML (Guindon et al., 2010) version 3.3.20180621 with the model GTR+I+G, selected through the Akaike's information criterion within jModelTest 2.1.10 program (Darriba et al., 2012). The tree branch support indexes were determined by bootstrap resampling with 1,000 replicates. Orthology was defined by sequence identity and genomic context conservation (synteny) using retrieved sequences from TriTrypDB (Aslett et al., 2010), after search for the chitinase gene.

\section{Ethics statement}


Source of DNA from human, used as controls in PCR diagnostic reactions was described in other study of our research group (Suzuki et al., 2016) and were obtained from patients of Marilia city, an endemic visceral leishmaniasis locality, localized in São Paulo, Brazil. The protocol of human samples, which were anonymized, was approved by Marilia Medical School Human Experimental Ethical Committee (CAAE 50128015.5.0000.5413). DNA from cats and DNA and sera of dogs collected in São Luis Island in the Brazilian State of Maranhão were gently donated by Dr. Andrea Pereira da Costa from Universidade Estadual do Maranhão, Brazil. DNA from phlebotomines were obtained from insects collected in Marilia city, localized in the Brazilian São Paulo State, with authorization by the Biodiversity Authorization and Information System (SISBIO), of the Chico Mendes Institute for Biodiversity Conservation (ICMBio), Brazilian Ministry of Environment (MMA), under number 64603-1 (10/18/2018).

\section{Results}

\section{Chitinase genetic locus conservation among Kinetoplastida supports its ancient origin and corroborate the Supercontinent Origin hypothesis for Leishmania genus}

In order to evaluate the phylogenetic relationship of the $\mathrm{GH} 18$ family chitinase in Kinetoplastida, we initially retrieved chitinase amino acid and nucleotide sequences from multiple trypanosomatids that were available in public databanks, and comparative analysis was performed using BLAST (Altschul et al., 1990). These results revealed that chitinase sequences are highly conserved within the Leishmania genus, with amino acid identity ranging from $78-100 \%$. Also, a similar GH18 Leishmania chitinase sequence was identified in the basal trypanosomatids Leptomonas, Strigomonas and Angomonas, with identity of $60 \%, 40 \%$ and $35 \%$, respectively, compared with Leishmania species. Our genomic searches also indicated that parasites from the Trypanosoma genus lacks this sequence. A protein with identity of $32 \%$ with the Leishmania genus chitinase was also present in Bodo saltans, the free living acquatic protozoa from the Order Kinetoplastida and belonging to the Family Bodonidae, which is commonly used as external group of Trypanosomatidae in phylogenetic studies, suggesting an early origin of this sequence and the occurrence of a homologous GH18 chitinase in an ancient Kinetoplastida lineage (Fig. 1A).

Using the TrytripDB genomic resources tools, the genomic contexts of chitinase-encoding gene from all available Kinetoplastida sequences, including B. saltans, Leptomonas, Angomonas, Strigomonas and Leishmania, showed to be conserved, further strengthening the hypothesis of a common origin. In all organisms included in the analysis, the GH18 chitinase appears as a single-copy gene (Fig. 1B).

A partial $953 \mathrm{bp}$ chitinase encoding gene fragment and the corresponding amino acid sequence from trypanosomatids available in genomic databanks and generated in this study was used for phylogenetic reconstruction using the maximum likelihood method (Fig. 1A). The phylogenetic reconstruction of Leishmania based on $\mathrm{GH} 18$ chitinase encoding gene corroborated the Supercontinent Origin of the Leishmania genus (Harkins et al., 2016) with high bootstrap support, showing a clear separation between 
L. (Leishmania) spp, L. (Viannia) spp. and L. (Paraleishmania) spp., with the single L. (Sauroleishmania) representative, L. tarentolae, appearing as a sister clade of L. (Leishmania) species (Fig. 1A).

Moreover, the BLAST analysis of the chitinase amino acid sequence from Bodo saltans showed identity of $38 \%$ with the chitinase of the marine microorganisms Perkinsus marinus and Micromonas pusilla. This suggests a possible marine environment origin in the trypanosomatids.

\section{Conventional PCR associated to restriction length polymorphism differentiated Leishmania subgenera of Old and New World.}

Next, we aimed to evaluate whether the chitinase-encoding sequence could be used as a molecular marker to differentiate Leishmania subgenera. For this, we initially performed in silico analyses of publicly available Leishmania chitinases deposited in GenBank, classified in the glycosil-hydrolase 18 (GH18) family (Table 1), localized in chromosome 16, and encoded by a single-copy gene, indicated high inter-subgenera identity in all important putative domains and post-translational modifications (Cabral et al., 2020).

The trypanosomatide chitinase genomic sequence alignment was used to select short sequences and specificity to amplify the corresponding gene from Leishmania genus species. After PCR analysis of several oligonucleotides sets on Leishmania, Trypanosoma, Lutzomyia, human, dog, and cat genomic DNA, the Lquit224F and Lquit1182R primers were found effective for molecular diagnosis. PCR with these oligonucleotides generated a $953 \mathrm{bp}$ fragment of the Leishmania chitinase encoding gene and it detected less than $100 \mathrm{fg}$ of DNA from Leishmania species of subgenus Leishmania (L. amazonensis, $L$. mexicana, L. infantum and L. donovani) and Viannia (L. shawi) (Fig. 2). Considering the genome size of Leishmania species of approximately $35 \mathrm{Mb}$ with a variation in the order of 10 (Schonian, 2017), sensitivity tests with the developed molecular diagnostic method revealed the detection of up to a single parasite with approximately $100 \mathrm{fg}$. The highest sensitivities were obtained with L. infantum and L. shawi genomic DNA.

The oligonucleotides L224_fow and L1182_rev were used to amplify and sequence the chitinase gene $953 \mathrm{bp}$ fragment from the species L. guyanensis, L. lainsoni, L. naiffi and L. shawi, all belonging to the Viannia subgenus, and from L. hertigi, which is grouped within the Paraleishmania. Of note, sequences for these representatives were not available in public genomic databanks. The obtained sequences were deposited in GenBank under accession numbers MN520614 to MN520618, and the chitinase fragment from the Viannia subgenus species presented 98 to $99 \%$ of identity among L. braziliensis, L. panamensis and $L$. peruviana, while the identity of the chitinase fragment from $L$. hertigi ranged from 79 to $83 \%$ of identity to the same Viannia subgenus species.

After restriction analysis of the $953 \mathrm{bp}$ chitinase fragment, the enzyme Pst / was effective for differential diagnosis of Old and New World Leishmania species from Leishmania, Viannia and Mundinia subgenera (Fig. 3). Separation between Old World Leishmania subgenus parasite species that cause VL and TL and 
between Sauroleishmania and Viannia subgenera were obtained with Dde / restriction analysis (Online resource 1 and 2).

\section{Discussion}

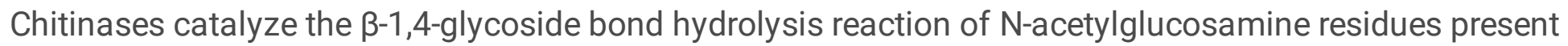
in chitins and chitodextrins (Cohen-Kupiec and Chet, 1998). Amino acid sequence similarity analysis indicated that these enzymes cluster in the $\mathrm{GH} 18$ and GH19 glycosyl hydrolase families. Chitinase and Nacetylglucosaminidase activities in Leishmania were initially found in promastigote supernatant cultures of $L$. (Leishmania) major. Apparently these enzymes were not secreted through the sand fly gut (Schlein, Jacobson, and Shlomai, 1991), thereby indicating chitinolytic action secreted by a specific parasite (Rogers, Chance, and Bates, 2002). The activity of both enzymes was observed in $L$. donovani, $L$. infantum, L. braziliensis, Leptomonas seymouri, Crithidia fasciculata and Trypanosoma lewisi. The molecular approach led to the identification and biochemical characterization of the gene encoding a GH18 chitinase from $L$. donovani (Ld Cht1). This sequence was found to be well distributed within the Leishmania genus (L. major, L. infantum, L. donovani and L. braziliensis) (Shakarian et al., 2010).

Homologous episomal overexpression of chitinase in both amastigotes and promastigotes of $L$. mexicana revealed an increase in vector transmission rate and increased pathogenicity in the vertebrate host, thereby indicating that chitinase plays an important role in parasite development, survival and transmission in mammalian hosts (Joshi et al., 2005; Rogers et al., 2008). However, the presence and role of this protein in human blood and tissues of leishmaniasis patients remain unknown. Given the importance of chitinase, its conservation across the Leishmania genus, species-specific amino acid and nucleotide sequence expression in all parasite developmental stages, in this work we geared our focus towards the study of chitinase-encoding gene as a molecular phylogenetic marker.

The genomic locus of GH18 chitinase encoding gene is conserved among basal trypanosomatids, including $B$. saltans and is absent in the Trypanosoma genus and also it was not found in genomic sequences of parasites from genus Phytomonas. In addition, amino acid sequence comparison among $\mathrm{GH} 18$ chitinases from trypanosomatids using public genome database revealed $35 \%$ identity of $\mathrm{GH} 18$ chitinases from marine protozoa and bacteria to the corresponding $B$. saltans ortholog. These results strongly suggest that the $\mathrm{GH} 18$ chitinase from the Kinetoplastida derived from a common marine ancestor, harboring the primitive enzyme. The phylogenetic reconstruction of basal trypanosomatids, based on the $\mathrm{GH} 18$ chitinase, corroborated the most accepted theory for Leishmania origin, the Supercontinent hypothesis (Harkins et al., 2016), which was based on a multigene analysis, with more than 200,000 nucleotides as informative sites. Thus, the GH18 chitinase, present in basal trypanosomatids, can be used as a molecular marker to identify unknown microorganisms, related to Leishmania genus, contributing to investigate the diversity and the evolutive history of this group.

The phylogenetic position of subgenus Sauroleishmania according to the Supercontinent hypothesis indicates the switch of its Leishmania ancestors from mammalian to reptilian hosts (Akhoundi et al., 
2016a). In considering a probable marine environment emergence of the trypanosomatid GH18 chitinase, it is possible to explore that the Sauroleishmania subgenus could diverge from an ancestor before the rise of mammals, during the transition of animals from marine to the terrestrial environment. In this case, parasites with similarity to basal groups of trypanosomatids could be found in fish and amphibians. Considering the conservation of the chitinase-encoding gene in Leishmania, the diagnostic method developed in this work can be used to investigate this hypothesis directly on biological samples, circumventing the isolation difficulties of unknown Leishmania related parasites.

Nucleic acid detection techniques in samples from people and/or animals infected with Leishmania, such as PCR, are used for detection and identification of the parasite since the 1980's. PCR include amplification of fragments of the gene encoding the small ribosomal RNA subunit (SSU rDNA,(van Eys et al., 1992), the transcribed internal ribosomal DNA spacer (ITS) (Schonian et al., 2003), sequences corresponding to kinetoplast (kDNA) (Cortes et al., 2004), mini-exon (Paiva et al., 2004), the gene encoding the heat shock protein HSP70, among others (da Silva et al., 2010). In spite of the high sensitivity of PCR and, depending on the molecular target, high specificity, it is more used in epidemiological studies than as a routine diagnostic method, and the gold standard method to diagnose Leishmania is the observation of the parasite by microscopic analysis (Thakur, Joshi, and Kaur, 2020). In addition, to achieve high sensitivity in the methodologies evaluated so far, PCR complementation with other techniques including nested PCR and hybridization is required. For identification of Leishmania species, the methodologies include restriction fragment size analysis of PCR products obtained, and as most of gene targets have multiple copies, interpretation of the results increases the difficulty of using these techniques in the clinical routine (Rogers et al., 2011; Ubeda et al., 2008). In addition, false positives are possible due to contamination with other post-PCR amplified samples or DNA fragments and crossreaction with other pathogens, including Trypanosoma (Degrave et al., 1994; Viol et al., 2012).

The differential diagnosis showed in this study, based on the detection of the $\mathrm{GH} 18$ chitinase gene, presents advantages over other molecular methods, since it employs a single copy gene, absent in Trypanosoma genus, enabling specific detection of Leishmania parasites. Also, the sensitivity of the method, regarding the large size of the amplified fragment supports post-PCR analysis after a single PCR reaction performed directly from biological samples. Restriction analysis of the $953 \mathrm{bp}$ Leishmania chitinase PCR fragment with Pst/permitted the identification of medically important species in Latin America where three different Leishmania subgenera circulates in animal reservoirs, human and sand flies (Fig. 2). Given the specificity of the Leishmania chitinase-encoding gene, the molecular diagnostic method can also be used to identify isolated parasites from biological samples, with high specificity, by restriction analysis and/or sequencing (Suzuki et al., 2016). Also, using the restriction enzyme D de Ion the 953 bp chitinase PCR fragment, it is possible to differentiate L. major from all others Old World Leishmania subgenus species, which is of clinical importance in Oriental TL endemic countries (Hijjawi et al., 2016) (Online resource 1 and 2).

Leishmania chitinase is present in basal groups of trypanosomatids genera, probably derived from an ancestor living in a marine environment, and unique in the human pathogen group. To the best of our 
knowledge, there are no Leishmania chitinase or homologous proteins described with a molecular structure associated to biochemical characterization. Considering the biological importance and the specificity of this protein to the Leishmania genus, molecular studies to define its biochemical function are warranted. Additionally, the diagnostic method described in this work enables detection of basal groups of trypanosomatids, directly from biological sources, helping in the identification of unknown species which may contribute to the Kinetoplastida evolutive history.

\section{Declarations}

\section{Funding}

This work was funded by Fundação de Amparo a Pesquisa do Estado de São Paulo (FAPESP) (Grant numbers 2016/14514-4 and 2012/20221-9; fellowships 2013/26096-4 and 2018/05133-2); by CAPES and UFABC. LGA is the recipient of a Master's scholarship from Fundação de Amparo à Pesquisa do Estado da Bahia (FAPESB; protocol BOL0159/2019).

\section{Conflicts of interest/Competing interests}

The authors have no conflicts of interest to declare that are relevant to the content of this article.

\section{Availability of data and material}

All data and materials as well as software application or custom code support their published claims and comply with field standards.

\section{Code availability}

Not applicable.

\section{Authors' contributions}

Conception, hypothesis, and design: Aline Diniz Cabral, Felipe Trovalim Jordão, Márcia Aparecida Sperança; all authors participated in data acquisition, analysis, read the manuscript and approved the final version.

\section{Ethics approval}

Source of DNA from human, used as controls in PCR diagnostic reactions was described in other study of our research group (Suzuki et al., 2016). The protocol of human samples, which were anonymized, was approved by Marilia Medical School Human Experimental Ethical Committee (CAAE 50128015.5.0000.5413). DNA from cats and DNA and sera of dogs were gently donated by Dr. Andrea Pereira da Costa from Universidade Estadual do Maranhão, Brazil. DNA from phlebotomines were obtained from insects collected with authorization by the Biodiversity Authorization and Information 
System (SISBIO), of the Chico Mendes Institute for Biodiversity Conservation (ICMBio), Brazilian Ministry of Environment (MMA), under number 64603-1 (10/18/2018).

\section{Consent to participate}

Not applicable.

\section{Consent for publication}

Not applicable.

\section{References}

1. Global leishmaniasis update, 2006-2015: a turning point in leishmaniasis surveillance. Wkly Epidemiol Rec 92, 557-65

2. Akhoundi M, Cannet A, Arab MK, Marty P, Delaunay P (2016a) An old lady with Pediculosis pubis on the head hair. J Eur Acad Dermatol Venereol 30:885-887. https://doi.org/10.1111/jdv.13050

3. Akhoundi M, Kuhls K, Cannet A, Votypka J, Marty P, Delaunay P, Sereno D (2016b) A Historical Overview of the Classification, Evolution, and Dispersion of Leishmania Parasites and Sandflies. PLoS Negl Trop Dis 10:e0004349. https://doi.org/10.1371/journal.pntd.0004349

4. Altschul SF, Gish W, Miller W, Myers EW, Lipman DJ (1990) Basic local alignment search tool. J Mol Biol 215:403-410. https://doi.org/10.1016/S0022-2836(05)80360-2

5. Alvar J, Velez ID, Bern C, Herrero M, Desjeux P, Cano J, Jannin J, den Boer M, Team WHOLC (2012) Leishmaniasis worldwide and global estimates of its incidence. PLoS One 7:e35671. https://doi.org/10.1371/journal.pone.0035671

\section{Archive EN, EMBL-EBI}

7. Aslett M, Aurrecoechea C, Berriman M, Brestelli J, Brunk BP, Carrington M, Depledge DP, Fischer S, Gajria B, Gao X, Gardner MJ, Gingle A, Grant G, Harb OS, Heiges M, Hertz-Fowler C, Houston R, Innamorato F, lodice J, Kissinger JC, Kraemer E, Li W, Logan FJ, Miller JA, Mitra S, Myler PJ, Nayak V, Pennington C, Phan I, Pinney DF, Ramasamy G, Rogers MB, Roos DS, Ross C, Sivam D, Smith DF, Srinivasamoorthy G, Stoeckert CJ Jr, Subramanian S, Thibodeau R, Tivey A, Treatman C, Velarde G, Wang H (2010) TriTrypDB: a functional genomic resource for the Trypanosomatidae. Nucleic Acids Res 38:D457-D462. https://doi.org/10.1093/nar/gkp851

8. Benson DA, Karsch-Mizrachi I, Lipman DJ, Ostell J, Wheeler DL (2004) GenBank: update. Nucleic Acids Res 32:D23-D26. https://doi.org/10.1093/nar/gkh045

9. Burland TG (2000) DNASTAR's Lasergene sequence analysis software. Methods Mol Biol 132:7191. https://doi.org/10.1385/1-59259-192-2:71

10. Cabral AD, Garcia FB, Suzuki RB, Filho G, da Costa TL, Vasconcelos RT, Santos LMP, E.S. and Speranca MA (2020) Dataset on recombinant expression of an ancient chitinase gene from different 
species of Leishmania parasites in bacteria and in Spodoptera frugiperda cells using baculovirus. Data Brief 32:106259. https://doi.org/10.1016/j.dib.2020.106259

11. Cohen-Kupiec R, Chet I (1998) The molecular biology of chitin digestion. Curr Opin Biotechnol 9:270277. https://doi.org/10.1016/s0958-1669(98)80058-x

12. Cortes S, Rolao N, Ramada J, Campino L (2004) PCR as a rapid and sensitive tool in the diagnosis of human and canine leishmaniasis using Leishmania donovani s.l.-specific kinetoplastid primers. Trans R Soc Trop Med Hyg 98:12-17. https://doi.org/10.1016/s0035-9203(03)00002-6

13. da Silva LA, de Sousa Cdos S, da Graca GC, Porrozzi R, Cupolillo E (2010) Sequence analysis and PCR-RFLP profiling of the hsp70 gene as a valuable tool for identifying Leishmania species associated with human leishmaniasis in Brazil. Infect Genet Evol 10:77-83. https://doi.org/10.1016/j.meegid.2009.11.001

14. Darriba D, Taboada GL, Doallo R, Posada D (2012) jModelTest 2: more models, new heuristics and parallel computing. Nat Methods 9:772. https://doi.org/10.1038/nmeth.2109

15. Degrave W, Fernandes O, Campbell D, Bozza M, Lopes U (1994) Use of molecular probes and PCR for detection and typing of Leishmania-a mini-review. Mem Inst Oswaldo Cruz 89:463-469. https://doi.org/10.1590/s0074-02761994000300032

16. Edgar RC (2004) MUSCLE: a multiple sequence alignment method with reduced time and space complexity. BMC Bioinformatics 5:113. https://doi.org/10.1186/1471-2105-5-113

17. Georgiadou SP, Makaritsis KP, Dalekos GN (2015) Leishmaniasis revisited: Current aspects on epidemiology, diagnosis and treatment. J Transl Int Med 3:43-50. https://doi.org/10.1515/jtim2015-0002

18. Guindon S, Dufayard JF, Lefort V, Anisimova M, Hordijk W, Gascuel O (2010) New algorithms and methods to estimate maximum-likelihood phylogenies: assessing the performance of PhyML 3.0. Syst Biol 59:307-321. https://doi.org/10.1093/sysbio/syq010

19. Harkins KM, Schwartz RS, Cartwright RA, Stone AC (2016) Phylogenomic reconstruction supports supercontinent origins for Leishmania. Infect Genet Evol 38:101-109.

https://doi.org/10.1016/j.meegid.2015.11.030

20. Hijjawi N, Kanani KA, Rasheed M, Atoum M, Abdel-Dayem M, Irhimeh MR (2016) Molecular Diagnosis and Identification of Leishmania Species in Jordan from Saved Dry Samples. Biomed Res Int 2016, 6871739. https://doi.org/10.1155/2016/6871739

21. Joshi MB, Rogers ME, Shakarian AM, Yamage M, Al-Harthi SA, Bates PA, Dwyer DM (2005) Molecular characterization, expression, and in vivo analysis of LmexCht1: the chitinase of the human pathogen, Leishmania mexicana. J Biol Chem 280:3847-3861. https://doi.org/10.1074/jbc.M412299200

22. Marcili A, Speranca MA, da Costa AP, Madeira Mde F, Soares HS, Sanches Cde O, Acosta Ida C, Girotto A, Minervino AH, Horta MC, Shaw JJ, Gennari SM (2014) Phylogenetic relationships of Leishmania species based on trypanosomatid barcode (SSU rDNA) and gGAPDH genes: Taxonomic revision of Leishmania (L.) infantum chagasi in South America. Infect Genet Evol 25:44-51. https://doi.org/10.1016/j.meegid.2014.04.001 
23. Okonechnikov K, Golosova O, Fursov M, team U (2012) Unipro UGENE: a unified bioinformatics toolkit. Bioinformatics 28:1166-1167. https://doi.org/10.1093/bioinformatics/bts091

24. Paiva BR, Passos LN, Falqueto A, Malafronte Rdos S, Andrade HF Jr (2004) Single step polymerase chain reaction (PCR) for the diagnosis of the Leishmania (Viannia) subgenus. Rev Inst Med Trop Sao Paulo 46:335-338. https://doi.org/10.1590/s0036-46652004000600007

25. Rogers MB, Hilley JD, Dickens NJ, Wilkes J, Bates PA, Depledge DP, Harris D, Her Y, Herzyk P, Imamura H, Otto TD, Sanders M, Seeger K, Dujardin JC, Berriman M, Smith DF, Hertz-Fowler C, Mottram JC (2011) Chromosome and gene copy number variation allow major structural change between species and strains of Leishmania. Genome Res 21:2129-2142. https://doi.org/10.1101/gr.122945.111

26. Rogers ME, Chance ML, Bates PA (2002) The role of promastigote secretory gel in the origin and transmission of the infective stage of Leishmania mexicana by the sandfly Lutzomyia longipalpis. Parasitology 124:495-507. https://doi.org/10.1017/s0031182002001439

27. Rogers ME, Hajmova M, Joshi MB, Sadlova J, Dwyer DM, Volf P, Bates PA (2008) Leishmania chitinase facilitates colonization of sand fly vectors and enhances transmission to mice. Cell Microbiol 10:1363-1372. https://doi.org/10.1111/j.1462-5822.2008.01132.x

28. Scheufele CJ, Giesey RL, Delost GR (2020) The global, regional, and national burden of leishmaniasis: An ecological analysis from the Global Burden of Disease Study 1990-2017. J Am Acad Dermatol. https://doi.org/10.1016/j.jaad.2020.08.043

29. Schlein Y, Jacobson RL, Shlomai J (1991) Chitinase secreted by Leishmania functions in the sandfly vector. Proc Biol Sci 245:121-126. https://doi.org/10.1098/rspb.1991.0097

30. Schonian G (2017) Genetics and Evolution of Leishmania parasites. Infect Genet Evol 50:93-94. https://doi.org/10.1016/j.meegid.2017.03.016

31. Schonian G, Nasereddin A, Dinse N, Schweynoch C, Schallig HD, Presber W, Jaffe CL (2003) PCR diagnosis and characterization of Leishmania in local and imported clinical samples. Diagn Microbiol Infect Dis 47:349-358. https://doi.org/10.1016/s0732-8893(03)00093-2

32. Shakarian AM, McGugan GC, Joshi MB, Stromberg M, Bowers L, Ganim C, Barowski J, Dwyer DM (2010) Identification, characterization, and expression of a unique secretory lipase from the human pathogen Leishmania donovani. Mol Cell Biochem 341:17-31. https://doi.org/10.1007/s11010-0100433-6

33. Suzuki RB, Cabral AD, Martins LP, Speranca MA (2016) A highly sensitive Leishmania infantum chagasi isolation method from bone marrow and peripheral blood of adults and children. $J$ Infect Dev Ctries 10:1275-1277. https://doi.org/10.3855/jidc.8022

34. Thakur S, Joshi J, Kaur S (2020) Leishmaniasis diagnosis: an update on the use of parasitological, immunological and molecular methods. J Parasit Dis, 1-20. https://doi.org/10.1007/s12639-02001212-w

35. Ubeda JM, Legare D, Raymond F, Ouameur AA, Boisvert S, Rigault P, Corbeil J, Tremblay MJ, Olivier M, Papadopoulou B, Ouellette M (2008) Modulation of gene expression in drug resistant Leishmania is 
associated with gene amplification, gene deletion and chromosome aneuploidy. Genome Biol 9:R115. https://doi.org/10.1186/gb-2008-9-7-r115

36. van Eys GJ, Schoone GJ, Kroon NC, Ebeling SB (1992) Sequence analysis of small subunit ribosomal RNA genes and its use for detection and identification of Leishmania parasites. Mol Biochem Parasitol 51:133-142. https://doi.org/10.1016/0166-6851(92)90208-2

37. Viol MA, Lima VM, Aquino MC, Gallo G, Alves IP, Generoso D, Perri SH, Lucheis SB, Langoni H, Nunes CM, Bresciani KD (2012) Detection of cross infections by Leishmania spp. and Trypanosoma spp. in dogs using indirect immunoenzyme assay, indirect fluorescent antibody test and polymerase chain reaction. Parasitol Res 111:1607-1613. https://doi.org/10.1007/s00436-012-2999-2

38. Ye J, Coulouris G, Zaretskaya I, Cutcutache I, Rozen S, Madden TL (2012) Primer-BLAST: a tool to design target-specific primers for polymerase chain reaction. BMC Bioinformatics 13:134. https://doi.org/10.1186/1471-2105-13-134

39. Zuker M (2003) Mfold web server for nucleic acid folding and hybridization prediction. Nucleic Acids Res 31:3406-3415. https://doi.org/10.1093/nar/gkg595

\section{Tables}

Table 1. Nucleotide sequences information 


\begin{tabular}{|c|c|c|c|}
\hline Species & Gene & Source & Observations \\
\hline $\begin{array}{l}\text { Angomonas } \\
\text { deanei }\end{array}$ & chitinase & ENA $^{2}:$ EPY25377 & \\
\hline $\begin{array}{l}\text { Blechomonas } \\
\text { ayalai }\end{array}$ & chitinase & Tritrypdb 3 :rna_Baya_138_0020-1 & B08-376 \\
\hline Bodo saltans & chitinase & Genbank CYKH01001162 & Locus sequence \\
\hline C. fasciculata & chitinase & Tritrypdb::CFAC1_120016000 & strain $\mathrm{Cf}-\mathrm{Cl}$ \\
\hline $\begin{array}{l}\text { Endotrypanum } \\
\text { monterogeii }\end{array}$ & chitinase & Tritrypdb:EMOLV88_160012400.1 & strain LV88 \\
\hline $\begin{array}{l}\text { Fimbriiglobus } \\
\text { ruber }\end{array}$ & chitinase & Genbank OWK46432.1 & $\begin{array}{l}\text { Bacterium from Order } \\
\text { Planctomycetales, } \\
\text { associated to Crustacea }\end{array}$ \\
\hline Homo sapiens & chitinase & Genbank AAG10644.1 & $\begin{array}{l}\text { Chitotriosidase, } \\
\text { Macrofago, } \mathrm{CH} 1 ; \mathrm{GH} 18\end{array}$ \\
\hline L. amazonensis & chitinase & Genbank: MG869127 & Strain IOCL 0575 \\
\hline L. braziliensis & chitinase & Genbank LS997615 & MHOM/BR/75/M2904 \\
\hline L. donovani & chitinase & Genbank CP019523 & $\begin{array}{l}\text { Strain } \\
\text { MHOM/IN/1983/AG83 }\end{array}$ \\
\hline L. enrietti & chitinase & Tritrypdb:LENLEM3045_160013500.1 & Strain LEM 3045 \\
\hline L. gerbilli & chitinase & Tritrypdb:LGELEM452_160013100.1 & Strain LEM452 \\
\hline L. guyanensis & chitnase & ENA:CCM15041 & \\
\hline L. infantum & chitinase & Genbank:FR796448 & Strain JPCM5 \\
\hline L. major & chitinase & Genbank:FR796412.1 & Strain Friedlin \\
\hline L. Mexicana & chitinase & Genbank:AY572789 & \\
\hline L. panamensis & chitinase & Genbank CP009385 & $\begin{array}{l}\text { Strain } \\
\text { MHOM/PA/94/PSC-1 }\end{array}$ \\
\hline L. peruviana & chitinase & Genbank LN609244 & PAB 4377 \\
\hline L. tarantolae & Chitinase & Tritrypdb:LtaP16.0770 & Parrot-Tarll \\
\hline L. tropica & Chitinase & TritrypdbLTRL590_160013800.1 & Strain L590 \\
\hline L. turanica & Chitinase & Tritrypdb:LTULEM423_160013000.1 & Strain LEM 423 \\
\hline $\begin{array}{l}\text { Leptomonas } \\
\text { pyrrhocoris }\end{array}$ & chitinase & Tritrypdb:rna_LpyrH10_15_0870 & $\mathrm{H} 10$ \\
\hline $\begin{array}{l}\text { Leptomonas } \\
\text { seymori }\end{array}$ & chitinase & Tritrypdb:PCLsey_0068_0030 & ATCC 30220 \\
\hline
\end{tabular}




\begin{tabular}{|c|c|c|c|}
\hline $\begin{array}{l}\text { Lutzomyia } \\
\text { longipalpis }\end{array}$ & chitinase & Genbank AAN71763.1 & GH18 chitinase \\
\hline $\begin{array}{l}\text { Micromonas } \\
\text { pusilla }\end{array}$ & chitinase & Genbank XP_003063458.1 & $\begin{array}{l}\text { Marine photosynthetic } \\
\text { eukaryotic } \\
\text { microorganism }\end{array}$ \\
\hline $\begin{array}{l}\text { Paratrypanosoma } \\
\text { confusum }\end{array}$ & chitinase & Tritrypdb:PCON_0062580 & Isolate cul13 \\
\hline Perkinsus marinus & chitinase & Genbank XM_002788039.1 & $\begin{array}{l}\text { Eukaryotic } \\
\text { microorganism, } \\
\text { pathogen of oysters }\end{array}$ \\
\hline $\begin{array}{l}\text { Phlebotomus } \\
\text { papatasi }\end{array}$ & chitinase & Genbank AAV49322.1 & GH18 chitinase \\
\hline Planktomyces sp & chitinase & Genbank OAI56776.1 & $\begin{array}{l}\text { Bacterium from marine } \\
\text { environment }\end{array}$ \\
\hline $\begin{array}{l}\text { Strigomonas } \\
\text { culicis }\end{array}$ & chitinase & ENA:EPY22137 & 522 amino acids \\
\hline $\begin{array}{l}\text { Strigomonas } \\
\text { culicis }\end{array}$ & chitinase & ENA:EPY29957 & 311 amino acids \\
\hline
\end{tabular}

1.Genbank(Benson et al., 2004); 2. ENA: European Nucleotide Archive(Archive) ; 3. TritrypDB(Aslett et al., 2010) : Kinetoplastid Genomics Resource.

\section{Figures}

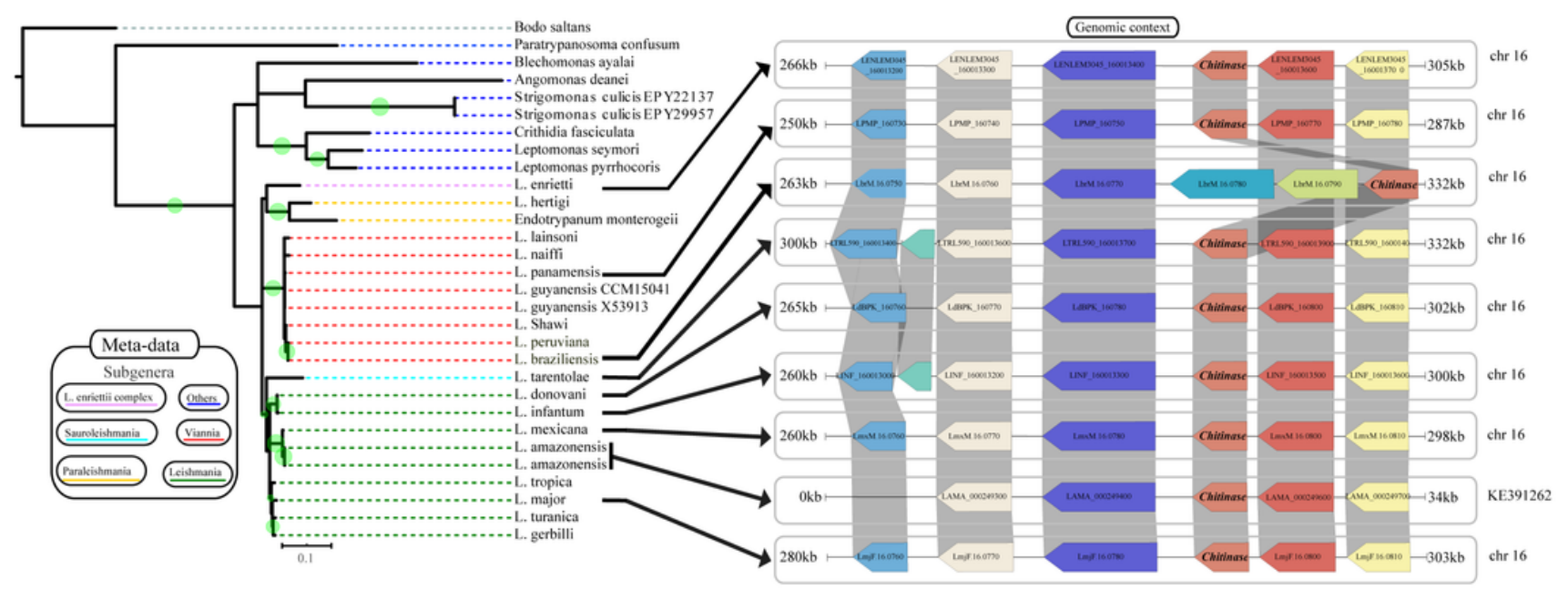

Figure 1 
Maximum likelihood phylogenetic tree and genomic context of the trypanosomatid chitinase $\mathrm{GH} 18$ encoding gene. A) maximum likelihood phylogenetic tree representing the evolutionary history of the chitinase from basal trypanosomatid representatives. Bootstrap support values (1,000 replicates) greater than $80 \%$ are represented by a green circle in the branches of the tree. Colored dashes indicate the subgenus for each species according to the legend. Each gene is depicted as an arrow (where direction reflects gene orientation), and the connecting gray segments indicate sequence conservation (nucleotide identity $\geq 90 \%$ ) among the genomic contexts.

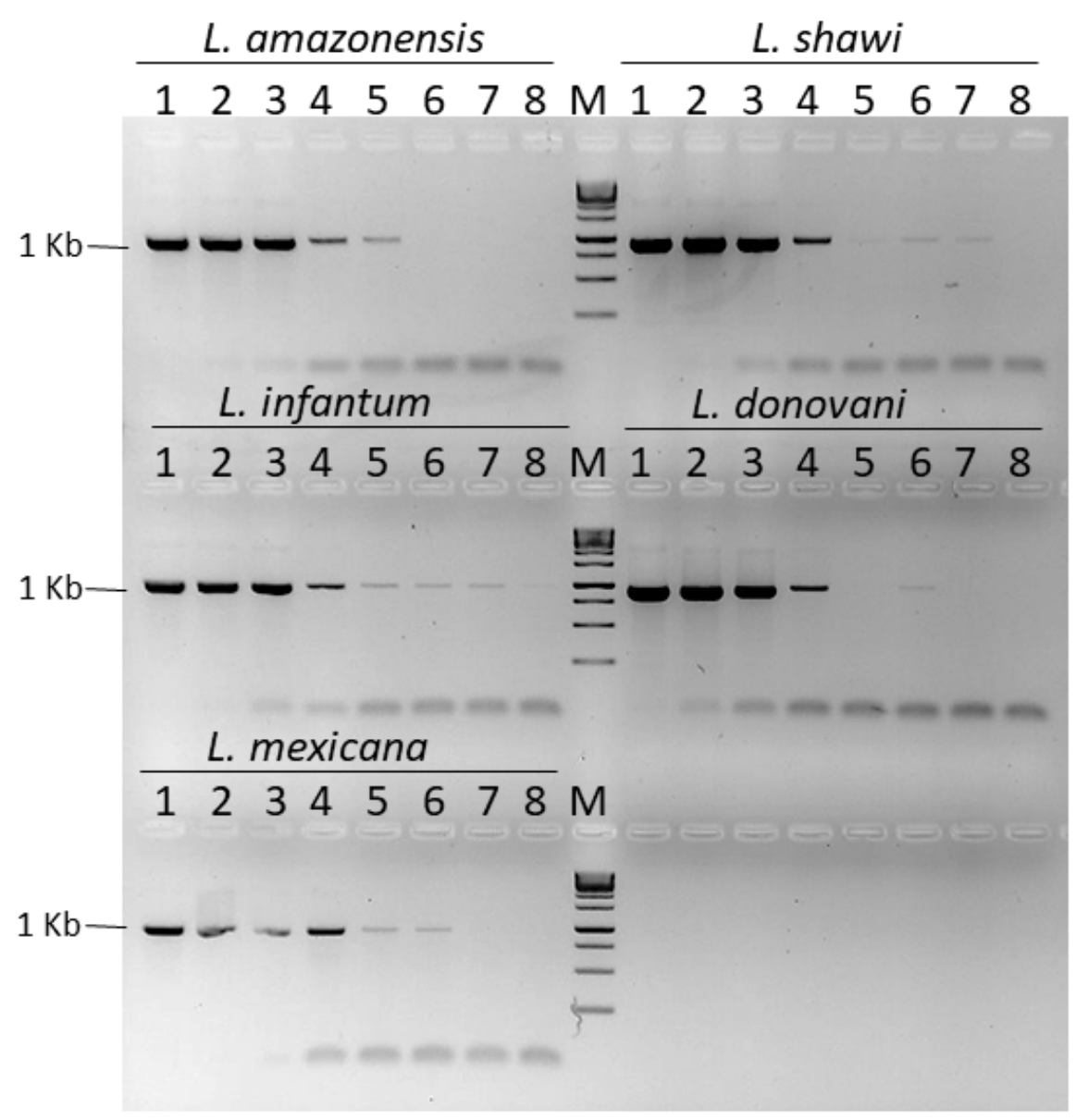


Figure 2

Sensitivity test of the $953 \mathrm{bp}$ Leishmania chitinase encoding gene fragment amplification by PCR. $2 \%$ agarose gel electrophoresis stained with UniSafe containing the PCR products after PCR with the oligonucleotides L224_fow e L1182_rev on genomic DNA of Leishmania genus species; M. 1Kb ladder (GeneO'ruler); 1-8 different concentrations of genomic DNA: 10ng, 1ng, 100pg, 10pg, 1pg, 100fg, 10fg and $1 \mathrm{fg}$, respectively.

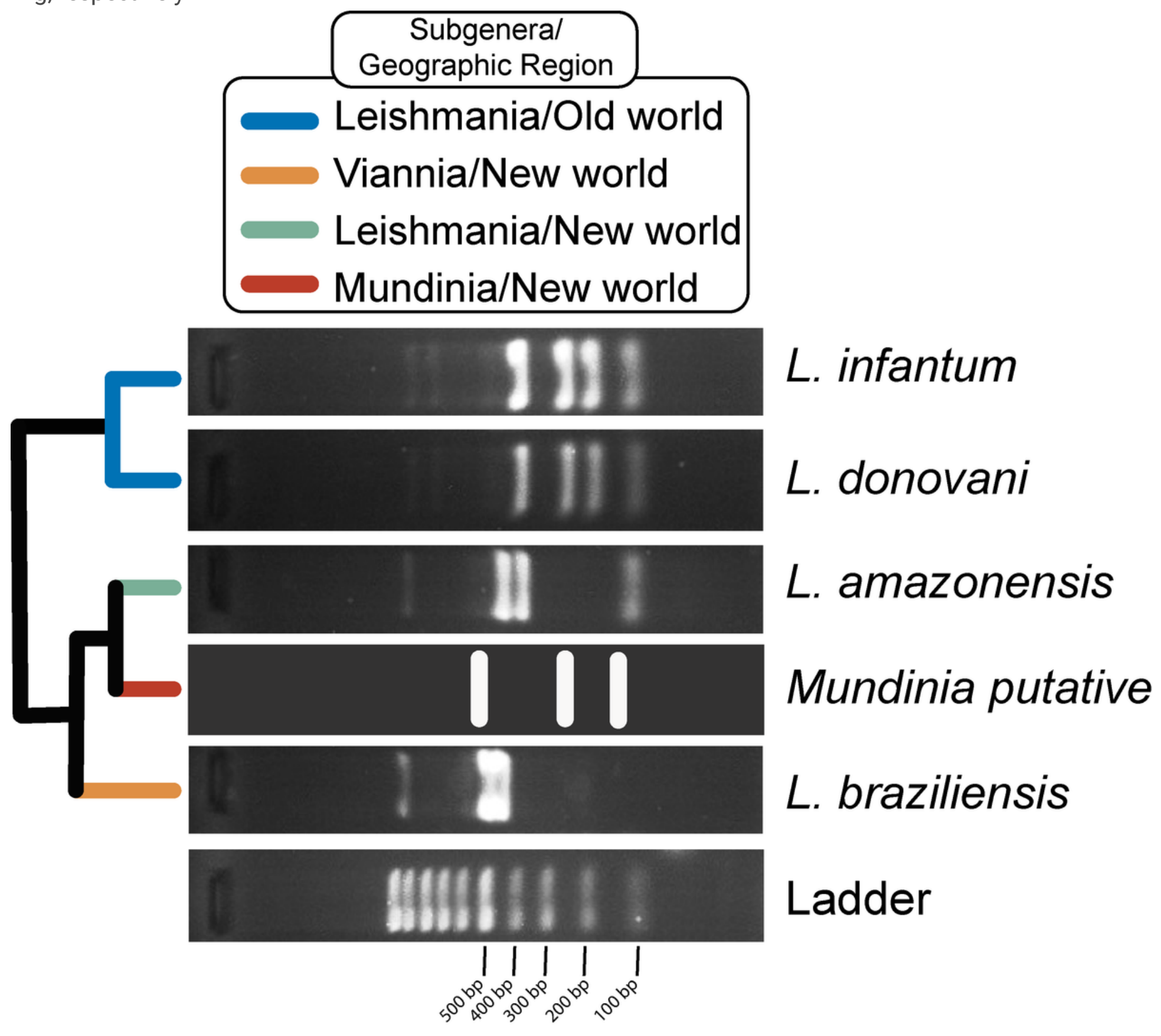

Figure 3

Differential diagnosis of Leishmania species by amplification of a 953 DNA fragment corresponding to chitinase encoding gene by PCR and restriction length size polymorphism using Pstl. Subgenera and corresponding geographic distribution are resumed in the upper square represented by colored lines. The 
size of the restriction fragments is shown in a 3\% agarose gel electrophoresis stained with UniSafe containing the Pstl restriction fragments of the $953 \mathrm{bp}$ Leishmania chitinase encoding gene PCR fragment. $\mathrm{M}-100$ bp ladder (GeneO'ruler)

\section{Supplementary Files}

This is a list of supplementary files associated with this preprint. Click to download.

- onlineresource1and2.docx 